\title{
POSTPHAGOCYTIC BACTERICIDAL ACTIVITY OF BUFFALO (BUBALUS BUBALIS) NEUTROPHILS AGAINST MASTITIS CAUSING BACTERIA
}

\author{
INDIRA SILVA* and S. KARIYAWASAM \\ Department of Clinical Studies, Faculty of Veterinary Medicine \& Animal \\ Science, University of Peradeniya, Peradeniya.
}

(Received: 25 April 1995; accepted: 01 March 1996)

\begin{abstract}
The postphagocytic bactericidal activity (PPBA) of buffalo neutrophils for mastitis causing bacteria, namely, Staphylococcus aureus, Streptococcus agalactiae and Escherichia coli, was studied. The percent phagocytosis (PP) and the PPBA were optimum at 45 and $60 \mathrm{~min}$, respectively, for all three bacteria. The PP was highest for Staph. aureus (88\%) followed by $E$. coli (86\%) and Strep. agalactiae ( $81 \%)$. The bacterial resistance to neutrophil bactericidal activity was evident by the absence of PPBA in varying degree, in all of the phagocytically active neutrophils. The neutrophil bactericidal activity was similar for all three bacteria, although, relatively higher for $E$. coli. This was evident by the total inhibition of PPBA in $31 \%$ of neutrophils by $E$. coli in comparison to an inhibition in $36 \%$ of neutrophils by Staph. aureus and Strep. agalactiae.
\end{abstract}

Key words: Bacteria, bactericidal activity, buffalo, mastitis, neutrophils.

\section{INTRODUCTION}

The phagocytic cells are the most important defense mechanism against infections in the mammary gland, other than the defense mechanisms in the teat and neutrophils are the most prominent cells in buffalo milk. ${ }^{1,2}$ In response to an insult, the cells in the mammary gland release mediators which induce an increase in capillary permeability, resulting in a breakdown of the blood-milk barrier. ${ }^{1,3}$ This results in transudation of serum proteins and recruitment of leukocytes, mainly neutrophils, into the lacteal secretion. ${ }^{4,5}$ These responses are critical to the cow's ability to survive a microbial challenge and to return to normal production. Neutrophils protect the bovine udder from pathogens by their phagocytic and microbicidal activities. The transit time for blood neutrophils to gain access to bacteria in the lacteal secretion is approximately $2 \mathrm{~h}^{1,6}$

The phagocytic events stimulate metabolic processes in the neutrophils leading to activation of microbicidal mechanisms. Bacterial resistance to phagocytosis and killing by neutrophils are dependent on a variety of bacterial properties such as capsule, cell wall composition, toxins and metabolic inhibitors. ${ }^{7}$ Leukocytes with impaired microbicidal mechanisms migrating from blood to milk will undoubtedly permit establishment of a new infection or the ultimate progression of an existing infection. ${ }^{3,8-10}$

\footnotetext{
* Corresponding author.
} 
Although the milking buffaloes are known to be more resistant to mastitis than cattle, udder infections can present a serious problem in the large herds due to poor hygiene. ${ }^{11,12}$ Staphylococci, streptococci and coliforms are the common mastitis causing bacteria. ${ }^{3,12}$ A simultaneous comparative evaluation of the phagocytic activity of buffalo blood neutrophils revealed a higher activity for Staphylococcus aureus, followed by similar activity for Streptococcus agalactiae and Escherichia coli. ${ }^{13}$ In the event of a mixed infection, a majority of cells preferentially phagocytized one species of bacteria and the affinity for phagocytizing $E$. coli was less in the presence of Staph. aureus or Strep. agalactiae. ${ }^{14}$

The objective of this study was to observe the bactericidal efficiency of buffalo neutrophils, to study their protective role in mammary infections. The supra vital dye eosin was used as an indicator of the viability of the phagocytized bacteria. ${ }^{15,16}$

\section{METHODS AND MATERIALS}

About $25 \mathrm{ml}$ blood from each of 9 Lankan buffaloes (Bubalus bubalis) were collected into vacutainers containing EDTA, by jugular venepuncture, according to the ethical guidelines. Blood was collected also into two $10 \mathrm{ml}$ vacutainers without anticoagulant to obtain fresh serum. The age of the buffaloes varied from 6 to $12 y$.

Isolation of neutrophils from buffalo blood: The neutrophils were isolated and the viability was tested as described earlier. ${ }^{13,17}$ The viability of the isolated cell suspension varied from 96 to $100 \%$ and consisted of $80-90 \%$ neutrophils. A working suspension of $10^{4}$ viable neutrophils $/ \mu \mathrm{l}$ in sterile $0.8 \% \mathrm{NaCl}$ in $0.0132 \mathrm{M}$ phosphate buffer, $\mathrm{pH} 7.2$ (PBS) with $2 \%$ bovine serum albumin was prepared and kept at $4^{\circ} \mathrm{C}$ until used.

Preparation of bacterial cultures: E. coli (ATCC 25922), Staph. aureus (ATCC 29213) and Strep. agalactiae were isolated from bovine mastitic milk. Separate suspensions of the three bacteria were prepared to obtain a concentration of $1 \times 10^{6}$ organisms/ $\mu$ in PBS $^{17}$ and the three bacteria were opsonized separately using serum of the particular buffalo for each assay. ${ }^{13}$ A neutrophil : bacteria ratio of 1:50 was used for optimum phagocytosis.

$400 \mu$ l of opsonized E. coli, Staph. aureus and Strep. agalactiae were aliquoted separately into three glass tubes.

Preparation of Eosin B solution: A 5\% solution of Eosin B (C.I. 45400, Certistain), (BDH Chemicals Ltd., UK) in distilled water was used as a supra vital dye to differentiate the viable and nonviable bacteria intracellularly. 
Phagocytosis assay: In a single experiment run, the three suspensions of microorganisms were incubated with $200 \mu \mathrm{l}$ of Eosin B solution and $200 \mu \mathrm{l}$ of the neutrophil suspension prepared from one buffalo. In the negative control, the bacterial aliquot was substituted with PBS.

The assay was carried out as described earlier ${ }^{13}$ and thin air-dried smears were prepared at 30,45 and 60 min of incubation at $37^{\circ} \mathrm{C}$.

Staining and microscopic evaluation: When the unstained smears were observed under the microscope, the intracellular dead bacteria stained pink with eosin and the live bacteria remained colourless. However the intracellular organelles such as the nucleus and cytoplasm could not be differentiated. Therefore the smears were stained with $2 \%$ methyl green (MG), for $45 \mathrm{sec}$ to $1 \mathrm{~min}$, to clearly differentiate the neutrophil nucleus, the cytoplasm, and the ingested bacteria. The smears were examined under the oil immersion objective (X 100) of a phase contrast microscope.

The neutrophil nucleus stained green and the cytoplasm stained pink. The smears successfully demonstrated the intracellular dead bacteria which stained green with MG whereas, the intracellular live bacteria remained colourless. The bacteria which were colourless intracellularly (indicating they were alive) at the time of making the smear maintained the colourless appearance even after the smears were fixed and stained with MG. Most of the bacteria outside the neutrophils were colourless indicating they were alive while a few stained green and, therefore, were dead at the time of smear making.

The percent phagocytosis (PP) or the percentage of phagocytically active neutrophils (cells with ingested bacteria) was determined by counting a minimum of 200 neutrophils. Out of the neutrophils which had performed phagocytosis, the percentages of the following three categories were determined: (a) neutrophils which failed to kill any of the ingested bacteria, (b) neutrophils which had killed all the ingested bacteria, and (c) neutrophils which killed some but failed to kill all the ingested bacteria (with both live and dead intracellular bacteria). The neutrophils in the negative control (without bacteria) did not show ingested particles.

Statistical analysis: The means and the standard error of the means (SEM) were calculated for all the parameters measured. Statistical analysis was done using the two sample T-test at 5\% significance level. 


\section{RESULTS}

The packed cell volume and the total leukocyte and differential leukocyte counts of the buffaloes used were within the normal range for the buffalo. ${ }^{18}$ Table 1 shows the means and the SEM for the PP for the three bacteria at the different incubation periods. The PP increased with increasing incubation times at $37^{\circ} \mathrm{C}$ and was optimum at $45 \mathrm{~min}$ for all three bacteria. The PP was not significantly different between 45 and 60 minutes.

The post phagocytic bactericidal activity (PPBA) was determined by the presence of dead bacteria which stained green. The PPBA was not evident in all of the phagocytically active neutrophils. Some neutrophils showed PPBA on all the ingested bacteria whereas, a few neutrophils killed only some of the ingested bacteria.

Table 1 also gives the mean and the SEM for the percentages of neutrophils which showed PPBA for all the ingested bacteria, for only some of the ingested bacteria (incomplete PPBA), and which failed to kill any ingested bacteria (total inhibition of PPBA).

The PPBA increased with increasing incubation times and was most comparable between 30 and 60 min incubation times. The PPBA was similar for the three bacteria, although, the least resistance to PPBA was observed with $E$. coli where the total absence of PPBA was observed in $31 \%$ of neutrophils, which was significantly lower than the highest value obtained, which was $36.5 \%$ with Staph. aureus. However the resistance by E. coli to PPBA was not significantly different to that by Strep. agalactiae (36.2\%). This is because of the wider individual variation observed between animals for Strep. agalactiae, which is indicated in Table 1 by a larger SEM. The resistance by Staph. aureus and Strep. agalactiae (36.5\% and $36.2 \%$ respectively) were similer. This resistance to PPBA did not significantly reduce when the incubation period was increased from $45 \mathrm{~min}$ to $60 \mathrm{~min}$ for $E$. coli (36.2\% and 30.8\% neutrophils) and Strep. agalactiae $(39.1 \%$ and $36.2 \%$ neutrophils). However, the resistance to PPBA by Staph. aureus was significantly reduced at 60 min compared to $45 \mathrm{~min}$ (36.5\% and $39.2 \%$ neutrophils, respectively), suggesting that the speed or the progression of bactericidal activity was relatively slower for Staph. aureus. 
Table 1: Means (and SEM) of percent phagocytosis of buffalo neutrophils for mastitis causing bacteria and the means (and SEM) of percent neutrophils which killed all or some of the ingested bacteria, and those which failed to kill ingested bacteria.

\begin{tabular}{|c|c|c|c|c|c|c|}
\hline Bacteria & $\begin{array}{l}\text { Time } \\
(\min )\end{array}$ & $\mathrm{n}$ & $\begin{array}{l}\text { \% phago- } \\
\text { cytosis }\end{array}$ & $\begin{array}{l}\% \mathrm{~N} \\
\text { with all } \\
\text { killed } \\
\text { bacteria }\end{array}$ & $\begin{array}{l}\% \mathrm{~N} \\
\text { with all } \\
\text { live } \\
\text { bacteria }\end{array}$ & $\begin{array}{l}\% \mathrm{~N} \text { with } \\
\text { live \& } \\
\text { killed } \\
\text { bacteria }\end{array}$ \\
\hline \multirow{3}{*}{$\begin{array}{l}\text { Staphylo- } \\
\text { coccus } \\
\text { aureus }\end{array}$} & 30 & 9 & $\begin{array}{c}82^{\mathrm{A}, \mathrm{B} 1} \\
(1.5)\end{array}$ & $\begin{array}{c}33.8^{\mathrm{G}, \mathrm{H}, 7} \\
(1.8)\end{array}$ & $\begin{array}{c}60.3^{\mathrm{N}, \mathrm{P}, 8} \\
(2.2)\end{array}$ & $\begin{array}{c}5.9 \\
(1.1)\end{array}$ \\
\hline & 45 & 9 & $\begin{array}{l}88^{\mathrm{A}, 2} \\
(1.6)\end{array}$ & $\begin{array}{l}57.5^{\mathrm{G}} \\
(0.7)\end{array}$ & $\begin{array}{c}39.2^{\mathrm{N}, \mathrm{O}} \\
(1.1)\end{array}$ & $\begin{array}{c}3.4 \\
(0.7)\end{array}$ \\
\hline & 60 & 9 & $\begin{array}{l}88^{\mathrm{B}, 3} \\
(1.2)\end{array}$ & $\begin{array}{l}59.0^{\mathrm{H}} \\
(1.9)\end{array}$ & $\begin{array}{c}36.5^{\mathrm{O}, \mathrm{P}, 9} \\
(1.8)\end{array}$ & $\begin{array}{c}4.5 \\
(1.5)\end{array}$ \\
\hline \multirow[t]{3}{*}{$\begin{array}{l}\text { Escherichia } \\
\text { coli }\end{array}$} & 30 & 9 & $\begin{array}{l}77^{\mathrm{C}, \mathrm{D} 4} \\
(1.5)\end{array}$ & $\begin{array}{c}33.2^{1, \mathrm{~K}} \\
(1.7)\end{array}$ & $\begin{array}{c}63.1^{\mathrm{Q}, \mathrm{R}} \\
(1.6)\end{array}$ & $\begin{array}{l}3.6^{\mathrm{U}} \\
(0.7)\end{array}$ \\
\hline & 45 & 9 & $\begin{array}{l}84^{\mathrm{C}, 5 .} \\
(1.5)\end{array}$ & $\begin{array}{c}56.8^{\mathrm{I}, J} \\
(3.0)\end{array}$ & $\begin{array}{l}36.2^{Q} \\
(2.9)\end{array}$ & $\begin{array}{l}7.0^{\mathrm{U}} \\
(1.3)\end{array}$ \\
\hline & 60 & 9 & $\begin{array}{l}86^{D, 6} \\
(1.3)\end{array}$ & $\begin{array}{c}64.0^{J, \mathrm{~K}} \\
(1.6)\end{array}$ & $\begin{array}{c}30.8^{R, 9} \\
(1.5)\end{array}$ & $\begin{array}{c}5.1 \\
(0.7)\end{array}$ \\
\hline \multirow{3}{*}{$\begin{array}{l}\text { Strepto- } \\
\text { coccus } \\
\text { agalactiae }\end{array}$} & 30 & 8 & $\begin{array}{c}72^{\mathrm{E}, \mathrm{F}, 1,4} \\
(1.5)\end{array}$ & $\begin{array}{c}27.5^{\mathrm{L}, \mathrm{M}, 7} \\
(2.1)\end{array}$ & $\begin{array}{c}68.0^{\mathrm{S}, \mathrm{T}, 8} \\
(1: 8)\end{array}$ & $\begin{array}{c}4.5 \\
(1.1)\end{array}$ \\
\hline & 45 & 8 & $\begin{array}{l}78^{\mathrm{E}, 2,5} \\
(1.1)\end{array}$ & $\begin{array}{l}56.8^{\mathrm{L}} \\
(2.9)\end{array}$ & $\begin{array}{l}39.1^{\mathrm{S}} \\
(3.0)\end{array}$ & $\begin{array}{c}4.2 \\
(1.0)\end{array}$ \\
\hline & 60 & 8 & $\begin{array}{c}81^{F, 3,6} \\
(1.0)\end{array}$ & $\begin{array}{l}58.0^{\mathrm{M}} \\
(2.9)\end{array}$ & $\begin{array}{l}36.2^{\mathrm{T}} \\
(2.9)\end{array}$ & $\begin{array}{c}5.8 \\
(1.5)\end{array}$ \\
\hline
\end{tabular}

${ }^{\Lambda-U}$ Comparison of means within the same organism-means with the same superscript were significantly different $(\mathrm{P}<0.05)$.

${ }^{1.9}$ Comparison of means between two organisms-means with the same number were significantly different $(\mathrm{P}<0.05) . \mathrm{N}=$ neutrophils. 


\section{DISCUSSION}

The defense mechanisms of the mammary gland occasionally lose the battle with pathogens which result in the multiplication of bacteria and the release of toxins in the gland, leading to mastitis. The ability of neutrophils to phagocytise and kill microorganisms is the ultimate measure of their efficiency. ${ }^{19}$ The microbicidal mechanisms of neutrophils are either oxygen independent, such as the cytoplasmic granule content, and/or oxygen dependent, such as oxygen free radicals (superoxide anion, singlet oxygen, hydroxyl radical) and the $\mathrm{H}_{2} \mathrm{O}_{2} /$ myeloperoxidase/halide complex. ${ }^{1}$ Previous methods of measuring bactericidal activity had depended on counting viable bacterial colonies (on culture media) following incubation with the phagocytes, which was tedious, subjected to observer error and was relatively insensitive. ${ }^{19}$ Newer techniques were developed later, such as radioimmuno assay techniques, scanning electronmicroscopy and fluorochromy, which require sophisticated equipment and operator skill. ${ }^{19-21}$ The present study describes the use of the supra vital dye Eosin to visualize the bacteria which were killed by neutrophils, and the methodology is simple and requires an ordinary or a phase contrast microscope.

In the present study, the PP of buffalo neutrophils was highest for Staph. aureus $(88 \%)$, followed by $E$. coli $(86 \%)$ and $S$ trep. agalactiae $(81 \%)$ at $60 \mathrm{~min}$ interaction at $37^{\circ} \mathrm{C}$. However, the PPBA was not evident in all phagocytically active neutrophils, and the PPBA was similar for all three bacteria. The PPBA increased with increasing incubation periods which was also described by others. ${ }^{19}$ The bactericidal activity was relatively less for Staph. aureus and Strep. agalactiae as observed by the total inhibition of PPBA in $36 \%$ of neutrophils, in contrast to a total inhibition of PPBA in a lesser number of neutrophils (31\%) when interacted with E. coli. This indicated that the phagocytic activity of buffalo neutrophils was relatively high although the bactericidal activity was relatively low for Staph. aureus, in comparison with $E$. coli. The higher resistance of the buffaloes to mastitis caused by Staph. aureus than cattle ${ }^{12}$ is explained by the relatively high PP of buffalo neutrophils for Staph. aureus compared with Strep. agalactiae or E. coli, observed in the present study, and pevious findings, which suggested that the neutrophils which appear in buffalo milk are functionally more efficient than those of cattle. ${ }^{22}$

An in vitro bactericidal assay on cattle neutrophils using a radioassay technique showed that $37 \%$ of Strep. agalactiae was killed after $30 \mathrm{~min}$ incubation, and the bactericidal activity increased to $76 \%$ after $60 \mathrm{~min}{ }^{19}$ In contrast, the same workers demonstrated using electronmicroscopy, that at 30 min incubation all ingested bacteria appeared to be viable and some were undergoing multiplication. ${ }^{20}$ These findings suggest that an accurate estimation of the killing efficiency could be obtained only by direct observation of neutrophils which had performed phagocytosis, as described in the present study, rather than by indirect methods. 
The process of making a smear and air drying will inactivate or fix the cells in the smear. The staining of the smear will visualize the bacteria internalized by the phagocytically active neutrophils, irrespective of the viability of the bacteria just before the time of smear making. Therefore, the bacteria which were alive just before smear making (those which resisted the PPBA) will not be evident by such regular staining. Eosin is a supravital dye since live cells exclude eosin, while the dead cells which stain red with eosin can be observed using an ordinary microscope. ${ }^{15,16}$

Phagocytosis by neutrophils is an active process. However, during this process, the medium bathing the bacterium is also passively taken in by the neutrophil. In the present study, Eosin was allowed to be internalized by the neutrophils along with the bacteria. The internalized bacteria which survived (or resisted PPBA of neutrophils) at different incubation times were able to exclude eosin, and thus remained colourless on microscopic examination. This implies that the presence of eosin around the bacteria, did not allow a second stain such as MG to stain the bacteria:

\section{Acknowledgement}

This study was supported in part by the Swedish Agency for Research Cooperation and the Natural Resources, Energy, and Science Authority of Sri Lanka, (BF-62). We thank Dr. A. Dangolla for statistical analysis and K.R.J.K. Amararatne and K.A.M.J. Silva for technical assistance.

\section{References}

1. Jain N.C. (1976). Neutrophil leukocytes and inflammation of the bovinemammary gland. Theriogenology 6(2-3): 153-173.

2. Silva I.D. \& Silva K.F.S.T. (1994). Total and differential cell counts in buffalo (Bubalus bubalis) milk. Buffalo Journal 2: 133-137.

3. Kehrli M.E. jr. \& Shuster D.E. (1994). Factors affecting milk somatic cells and their role in health of the bovine mammary gland. Journal of Dairy Science 77: 619-627.

4. Giri S.N., Chen Z., Carroll E.J., Mueller R., Schiedt M.J. \& Panico L. (1984). Role of prostaglandins in pathogenesis of bovine mastitis induced by Escherichia coli endotoxin. American Journal of Veterinary Research 45:586-590.

5. Rose D.M., Giri S.N., Wood S.J. \& Cullor J.S. (1989). Role of leukotriene $B_{4}$ in the pathogenesis of Klebsiella pneumoniae induced bovine mastitis. American Journal of Veterinary Research 50: 915-918. 
6. Persson K, Sandgren C.H. \& Rodriguez-Martinez H. (1992). Studies of endotoxin-induced neutrophil migration in bovine teat tissues, using indium-III-labelled neutrophils and biopsies. American Journal of Veterinary Research 53: 2235-2238.

7. Henricks P.A.J., Verhoef J. \& Nijkamp F.P. (1986). Modulation of phagocytic cell function. Veterinary Research Communieations 10:165-188.

8. Kerhli M.E. jr. \& Goff J.P. (1989). Periparturient hypocalcaemia in cows: effects on peripheral blood neutrophil and lymphocyte function. Journal of Dairy Science 72:1188-1192.

9. Kerhli M.E. jr., Nonecke B.J. \& Roth J.A. (1989). Alterations in bovine peripheral blood neutrophil function during the periparturient period. American Journal of Veterinary Research 50: 207-210.

10. Nagahata H., Makino S., Takeda S., Takahashi H.\& Noda H. (1988). Assessment of neutrophil function in the dairy cow during the perinatal period. Journal of Veterinary Medicine. Series B 35: 747-750.

11. Uppal S.K., Singh K.B., Roy K.S., Nauriyal D.C. \& Bansal B.K. (1994). Natural defense mechanism against mastitis: a comparative histomorphology of buffalo and cow teat canal. Buffalo Journal 2:125-131.

12. Wanasinghe D.D. (1985). Mastitis among buffaloes in Sri Lanka. Proceedings of the 1st World Buffalo Congress (Brief communications) IV: 1331-1333.

13. Silva I.D. (1993). Phagocytic efficiency of buffalo (Bubalus bubalis) blood neutrophils for common mammary pathogens. Buffalo Journal 2:181-185.

14. Silva I.D. \& Thattil R.O. (1995). Preferential phagocytosis of bacteria in mixed cultures by buffalo (Bubalus bubalis) neutrophils. Journal of the National Science Council of Sri Lanka 23(1): 9-15.

15. Hafez E.S.E. (ed.) (1993). Reproduction in farm animals. 6th ed. Lea and Febiger, Philadelphia, USA.

16. Clark G. (ed.) (1981). Staining procedures. 4th ed. Williams and Wilkins, Baltimore, USA.

17. Silva I.D. \& Jain N.C. (1988). Phagocytic and nitroblue tetrazolium reductive properties of bovine neutrophils for mammary pathogens. Journal of Dairy Science 71: 1625-1631. 
18. Shukla P.C., Pande M.B., Desai H.B. \& Desai, M.C. (1981). Haematological and chemical status of blood of local cattle and buffaloes of Panchmahals district of Gujrat State. Indian Journal of Animal Research 15 (2): 103-106.

19. Mackie D.P., Pollock D.A. \& Logan E.F. (1982). In vitro bactericidal assay of bovine polymorphonuclear leukocytes agaisnt a group B streptococcus. Research in Veterinary Science 33: 240-242.

20. Mackie D.P., Pearson G.R., Curran W.L., Pollock D.A. \& Lodan E.F. (1982). Electron microscopic visualization of the in vitro phagocytosis of group $B$ streptococci by bovine polymorphonuclear leukocytes. Research in Veterinary Science 33: 333-337.

21. Goldner M., Farkas-Himsley H., Kormendy A. \& Skinner M. (1983). Bacterial phagocytosis monitored by fluorescence and extracellular quenching:ingestion and intracellular killing. Laboratory Medicine 14(5): 291-294.

22. Silva I.D. (1993). A comparison of the phagocytic efficiency of buffalo (Bubalus bubalis) blood and milk neutrophils. Sri Lanka Veterinary Journal 40(1): 7-14. 